\title{
The Periphyton Community Structure in the Habitat of Lawar (Perinereis cf.cultrifera Grube 1840) at Wearlilir Waters in the Southeast Maluku District Indonesia
}

\author{
Martha Rettob \\ State Fisheries Polytechnic of Tual, Jl. Langgur -Sathean Km.6 Southeast Maluku District 97611
}

\begin{abstract}
Lawar is an omnivorous benthic organisms (omnivores) and live in clean and clear waters, algae covered hard substrate, rocks, and reefs that have not been damaged. Therefore, not all coastal waters with similar characteristics, Lawar can be found at the same time of the harvest. This study aims to analyze the community structure of periphyton, the dominant kind, the kind that plays a role in the community and density types. The study was conducted for six months, from January to June 2012, using the line transect method for the acquisition of the data that were then analyzed using the Simpsons index and importance value index and density. The results obtained showed that the community structure is composed of 18 genera and 25 species. Community structure is stable because no species dominating other species where the species with more important role in the periphyton community is Geryonia proboscidalis in Lawar habitat with a density of 2.316 million cells/ $\mathbf{m l}$.
\end{abstract}

Keywords: Periphyton, Lawar, Habitat, Community structure

\section{Introduction}

Periphytons are groups of aquatic organisms that attach to the surface of the plants, sticks, stones, or other substrates that were in the water for example algae [5]. Periphyton can be grouped into four categories: epiphyton (organisms that live on the plant), epizoon (organisms that live in animals), epilithon (organisms that live on the rock), and epixylon (organisms that live on dead wood).

Factors that influence the development of periphyton in the waters include brightness, turbidity, substrate type, depth, water movement, flow, $\mathrm{pH}$, alkalinity, hardness, and nutrients. According to Rettob et al. (2011) [7], the high catchments of worms may bedue to the high values of temperature, $\mathrm{pH}$, and salinity. Relatively high dissolved oxygen levels ranged from 7.1 to $9.3 \mathrm{mg} / 1$., neutral $\mathrm{pH}$ between 7.5 to 8.5 ., Temperature of 28.4 to $31,2^{\circ} \mathrm{C}$, salinity 24-29 \%o. Highest Lawar biomass captured in September as much as $5921.43 \mathrm{~g} / \pm 2 \mathrm{dm} 3$ while the lowest was obtained in January in an amount of $33.65 \mathrm{~g}$. The development of periphyton decreased in areas protected from light. Increased turbidity due to silt and plankton can reduce the intensity of light entering the waters and thus block the periphyton on the basis that utilizes light to grow [9].

Lawar found in the waters clean and clear, hard substrate covered by algae, rocks, and reefs that have not been damaged, so as not all coastal waters with similar characteristics can be found worms P.cultrifera at the same time catchment [6]. The purpose of the study is to analyze the community structure of periphyton, dominating kind, the kind that play a role in the community, as well as the density of periphyton habitats of $P$. cultrifera Lawar in Wearlilir waters.

\section{Research Methods}

This study was carried out for six month at January until June 2012. The samplings of periphyton were done for six months, using a $50 \times 50 \mathrm{~cm}$ square of transect, sampling used two transects, four squares consisting of sixteen quadrants in each month with $50 \mathrm{~m}$ spacing between transects. Periphyton samples were obtained by scraping the surface of the substrate in each quadrant using different tooth brush. Samples were collected and then inserted into the sample bottle and given water and alcohol 50\%, then 1 $\mathrm{ml}$ of samples were taken with a pipette and dripped into the haemocytometer to count the number of individuals of each species. Identification periphyton type refers to the identification book by Yamaji (1984) [12] then the number of individual was calculated with a hand tally counter under a dissecting microscope type of XSZ-107BN No.000807 at $100 x$ magnification. Further data analysis of periphyton community structure include:

\section{a) The Simpsons Index}

The Simpsons index was used to determine the dominance of a particular species in a community. Value ranges from 0 1 , values $>0.4$ indicate a dominance of certain species in the community. The closer to 1 , the greater dominance of certain species in the community [1].

$\mathrm{Id}=\Sigma \mathrm{ni}(\mathrm{ni}-1)(\mathrm{N}(\mathrm{N}-1)-1$

Where, Id = dominance index

$\mathrm{ni}=$ Number of $\mathrm{i}$-th species

$\mathrm{N}=$ Total number of species found

\section{b) The Importance Value Index}

Analysis of Importance Value Index (IVI/INP) is performed to compute and predict the entirety of the role of a particular periphyton in a community. The formulas used are as follows:

$\mathrm{IVI}=\mathrm{KR}+\mathrm{FR}$ 


\section{International Journal of Science and Research (IJSR) \\ ISSN (Online): 2319-7064}

Index Copernicus Value (2013): 6.14 | Impact Factor (2015): 6.391

With, IVI = Importance Value Index

$\mathrm{FR}=$ relative frequency

$\mathrm{KR}$ = relative density

The higher the importance value of a type relative to the other types, the higher the role of types in the community [1].

\section{c) Density}

The density is obtained by multiplying the average results of individual number counted $(\mathrm{N})$ with $10^{4}$ or $\mathrm{N} \mathrm{x} 10^{4}$ cells / $\mathrm{ml}$.

\section{Results and Discussion}

The periphyton community structure in January consist of 5 genera and 6 species,such as Geryonia proboscidalis, unidentified (cyclopoid), unidentified caridean shrimp, roundworm (Nematoda), Globigerina pachyderma, Sphaerosyllis sublaevis, with a dominance type (D) of 0.32 so there were no other dominant species or community structure is in a stable state. The highest Important Value Index (IVI) is on Geryonia proboscidalis of 56.12 where the higher value indicates that the species Geryonia proboscidalis more involved in the community with a density of 492,000 cells / $\mathrm{ml}$.

In February and March,the periphyton community structure consists of 6 genera, 7 species namely Geryonia proboscidalis, Unidentified (cyclopoid), Unidentified caridean shrimp, roundworm (Nematoda), Globigerina pachyderma, Sphaerosyllis sublaevis, Limacina (Stiratella) lesueuri. Dominance value (D) of 0.30 , while the highest IVI was on Geryonia proboscidalis species at 55.39 and 55.21 in March. Community structure is in a stable state with a species that is more involved in the community is Geryonia proboscidalis with each density 642,000 cells/ ml and 564,000 cells/ ml. The periphyton community structure in April and May consist of Geryonia proboscidalis, Unidentified (cyclopoid), Unidentified caridean shrimp, roundworm (Nematoda), Globigerina pachyderma, Sphaerosyllis sublaevis and included in five genera, 6 species. The dominance value of each type was 0.34 and 0.33 while the value of the highest importance in April was 63.17 and 59.96 in May.

The results showed that no species dominates other species orthe periphyton community structure was in a stable state. Furthermore, species playing more role in the community in April was Unidentified caridean shrimp species and in May was Geryonia proboscidalis, with the density of each type was 642,000 cells / $\mathrm{ml}$ and 618,000 cells / ml. In June consists of 17 genera and 24 species with a dominance value of 0.16 while the value of the type of the highest importance at 30.10 on Unidentified caridean shrimp. There were no species dominating other species or community structure is stable. Species that are more involved in the community is Unidentified caridean shrimp at a density of 270,000 cells / $\mathrm{ml}$.

The results showed that the types of periphyton were obtained consisting of as many as 10 genera of zooplankton organisms and as many as eight genera of phytoplankton organisms. Periphyton community structure in Lawar $P$. cultrifera habitats in Wearlilir waters consists of 9 species phytoplankton (Table 1) and 15 species zooplankton (Table 2 ). Types of periphyton obtained in each observation time were six species, while Limacina (Stiratella) lesueuri species found only in February and June. According to Rettob et al., (2011) [7], on June to November, the periphyton species always obtained in the Wearlilir waters is Geryonia proboscidalis, Unidentified (cyclopoid), Unidentified caridean shrimp, roundworm (nematode), Globigerina pachyderma, Chaetoceros pelagicus, Limacina (Stiratella) lesueuri. The seven species are the primary species forming the periphyton community structure of Lawar in Wearlilir aquatic habitats.

The results showed that the amount of periphyton species were always found and is the major species in Lawar habitat and effecting the biomass as much as six to seven species. The periphyton community structure in Lawar habitats played a role in the growth and development of Lawar inWearlilir waters, especially the zooplankton types of Geryonia proboscidalis because this type is more involved in the community and has the highest density values. It is also associated with Lawar benthic organisms classified as omnivores type where the availability of food in the sediment may play an important role in determining the dynamics of deposit-feeders. Natural feed of the group peryphyton such Cyanophyceae, Chlorophyceae which serves as an important food source for invertebrates, tadpoles, and fish. Peryphyton also serves as an important indicator of water quality, and is able to remove pollutants and dissolved solid and capable reduce turbidity. Peryphyton have a rapid response to changes in water quality [2].

Average lowest biomass was in March and highest biomass was obtained in September. The low biomass occurs because of little catch, it is assumed that one contributing factor are existence of macro algae such as macro algae Padina sp, Ulva sp, Sargassum sp and Turbinaria sp were abundant in the bottom waters thus inhibiting movement of P.cultrifera worms to the surface waters. This is the impact of upwelling process in the Banda Sea. Flow lifting nutrients from bottom waters and into Wearlilir and Langgur waters from the south and out from the north with an average flow speed of $14 \mathrm{sec}$ / $\mathrm{m}$ causing the fertile waters so abundant with macroalgae in the bottom. According to Wood (1987) [11] that the range of $10-100 \mathrm{~cm} / \mathrm{sec}$ which is categorized as being beneficial to the organism in the bottom; updates occur between organic and inorganic materials and there is no accumulation. The presence of juvenile group in June to August due to the phenomena associated with the impact of upwelling in the Banda Sea that raised and spread the nutrients into the surface waters that support the growth of plankton which are then utilized by juveniles that later migrate vertically to the surface waters [8]. Furthermore, the waters chemical-physics factor triggers waters fertility and affect the growth of periphyton (plankton) and both affect the biomass of Lawar.

Furthermore, according to Ishida (2003) [3] that P.cultrifera consuming clean mucus released by Serpulorbis imbricatus gastropods by hiding itself on the shell gap S.imbricatus then out to catch and swallow the mucus. The S.imbricatus mucus work to catch suspension containing foods. P.cultrifera mostly catch S.imbricatus mucus at night 


\section{International Journal of Science and Research (IJSR) \\ ISSN (Online): 2319-7064}

Index Copernicus Value (2013): 6.14 | Impact Factor (2015): 6.391

because of the suspension period and the S.imbricatus increased feeding activity at night. Plants, particularly macrophytes and periphyton (bio-film), are amongst the most efficient organisms in removing dissolved nutrients in aquatic ecosystems. The former is mostly represented by vascular plants and few large algae [4], while the latter is a complex microbiota community (algae, bacteria, fungi, animals, inorganic and organic detritus) attached to inorganic or organic, living or dead substrata [10]. Referring to Ishida (2003) [3], it can be said that the mucus of S.imbricatus taken contain the food required by Lawar $P$. cultrifera resulting in the competition to acquire the food. Lawar as competitor to S.imbricatus in acquisition of food and it can be said that there is a symbiotic parasitism.

\section{Conclusion}

Periphyton community structure in Lawar $P$. cultrifera habitats in Wearlilir waters consists of 18 genera and 25 species. There is no other species dominating other species so the periphyton community structure is stable. The type with more roles in the community is Geryonia proboscidalis with a density of 2.316 million cells/ $\mathrm{ml}$.

\section{Acknowledgements}

My thanks to the team-work members; Vlavy, Hany, Roy, Andre, Eny, Esy et al. and Jehan.

\section{References}

[1] Brower, J., J Zar and C. von Ende. 1990. Field and Laboratory Methods for General Ecology. Wm. C. Brown Publ.

[2] Cholik, F., Ateng, G.,Jagatraya, Poernomo, .P., dan Ahmad, A. 2005. Akuakultur tumpuan harapan masa depan bangsa. Kerjasama Masyarakat Perikanan Nusantara dan Taman Akuarium Air Tawar, Taman Mini Indonesia Indah. Jakarta.
[3] Ishida, S. 2003. Nereididae polychaete Cacing Perinereis cultrifera ingesting vermetid imbricatus Serpulorbis Gastropod. http://Zoo_2.Zoo.Kyotou.ac.jp/ethol/show detail-e.php 19 Desember 2009

[4] Ikusima, I. and Gentil, JG. Ecological studies of aquatic macrophytes in four lakes. In Tundisi, JG. and Saijo, Y. (Eds.). Limnological studies of the Rio Doce Valley lakes. São Carlos: Brazilian Academy of Sciences, 1997. p. 309-323.

[5] Michael, P.1986. Ecological Methods for Field and Laboratory Investigations. Tata McGraw-Hill Publishing Company Limited New Delhi

[6] Rettob, M. 2007. Studi Beberapa Aspek Reproduksi Cacing Laut Cacing Perinereis cultrifera (Grube 1840) Yang Tertangkap Di Perairan Pantai Wearlilir Kepulauan Kei Kecil Kabupaten Maluku Tenggara, Tesis.Program Pascasarjana UNSRAT. Manado. 98p.

[7] Rettob, M., D. Arfiati., L.Hakim., dan L. Lumingas. 2011. Struktur Komunitas Perifiton dan Biomasa LawarPerinereis cultrifera (Grube 1840) Di Perairan Wearlilir Kabupaten Maluku Tenggara. Proceedings $2^{\text {nd }}$ National Conference on Green Technology EcoTechnology for Sustainable Living. Fakultas Sain dan Teknologi. UIN Maulana Malik Ibrahim Malang. Malang 12 Nopember 2011. Hal 26-29.

[8] Rettob. M. 2013. Aspek Fisika Kimia Perairan pada Habitat dan Biomassa Cacing Lawar Perinereis cultrifera (Grube 1840) Di Perairan Langgur Kabupaten Maluku Tenggara. Prosiding Seminar Nasional Kelautan dan Perikanan I, Universitas Nusa Cendana Kupang

[9] Weitzel,R.L. 1979. Methods and Measurements of Perifiton Communities: A Review American Society for Testing and Materials. Philadelphia

[10] Wetzel, RG. Periphyton of freshwater ecosystems. The Hague: Dr. W. Junk Publishers, 1983a. (Developments in Hydrobiology, 17)

[11] Wood, M. S. 1987. Subtidal ecology. Edward Arnold Pty. Limited, Australia.

[12] Yamaji, I. 1984. Illustrations of The Marine Plankton of Japan. Hoikusha, Publishing Co.Ltd, Japan. 531p

Table 1: The Community Structure Phytoplankton in Habitat of Lawar at Wearlilir Waters

\begin{tabular}{|c|c|c|c|c|c|c|c|}
\hline \multirow[t]{2}{*}{ No } & \multirow[t]{2}{*}{ Name Species } & \multicolumn{6}{|c|}{ Research Time } \\
\hline & & January & Pebruary & March & April & May & June \\
\hline 1 & Chaetoceros pelagicus & - & - & - & - & - & + \\
\hline 2 & Chaetoceros pendulus & - & - & - & - & - & + \\
\hline 3 & Bacteriastrum varains var nipida & - & - & - & - & - & + \\
\hline 4 & Cochlonidium schuettii & - & - & - & - & - & + \\
\hline 5 & Thalasionema nitzchioide & - & - & - & - & - & + \\
\hline 6 & Rhabdonema adriaticum & - & - & - & - & - & + \\
\hline 7 & Thalasiothrix franenfeldii & - & - & - & - & - & + \\
\hline 8 & Diatoma hialina & - & - & - & - & - & + \\
\hline 9 & Trichodesmium eritraeum & - & - & - & - & - & + \\
\hline & $\Sigma$ & $\mathbf{0}$ & $\mathbf{0}$ & $\mathbf{0}$ & $\mathbf{0}$ & $\mathbf{0}$ & 9 \\
\hline
\end{tabular}




\section{International Journal of Science and Research (IJSR) \\ ISSN (Online): 2319-7064}

Index Copernicus Value (2013): 6.14 | Impact Factor (2015): 6.391

Table 2: The Community Structure Zooplankton in Habitat of Lawar at Wearlilir Waters

\begin{tabular}{|c|c|c|c|c|c|c|c|}
\hline \multirow[t]{2}{*}{ No } & \multirow[t]{2}{*}{ Name Species } & \multicolumn{6}{|c|}{ Research Time } \\
\hline & & January & Pebruary & March & April & May & June \\
\hline 1 & Geryonia proboscidalis & + & + & + & + & + & + \\
\hline 2 & unidentified (cyclopoid) & + & + & + & + & + & + \\
\hline 3 & unidentified caridean shrimp & + & + & + & + & + & + \\
\hline 4 & roundworm (Nematoda) & + & + & + & + & + & + \\
\hline 5 & Globigerina pachyderma & + & + & + & + & + & + \\
\hline 6 & Globigerina calida & - & - & - & - & - & + \\
\hline 7 & Tintiniopsis iprica & - & - & - & - & - & + \\
\hline 8 & Labidocera kroyeri & - & - & - & - & - & + \\
\hline 9 & Labidocera pavo & - & - & - & - & - & + \\
\hline 10 & Glaucus atlanticus & - & - & - & - & - & + \\
\hline 11 & Sphaerosyllis sublaevis & + & + & + & + & + & + \\
\hline 12 & Sphaerosylli erinaceus & - & - & - & - & - & + \\
\hline 13 & Lepidosthenia grimaldi & - & - & - & - & - & + \\
\hline 14 & Limacina (Stiratella) lesueuri & - & + & + & - & - & + \\
\hline 15 & Calanus bracialis & - & - & - & - & - & + \\
\hline & $\Sigma$ & 6 & 7 & 7 & 6 & 6 & 15 \\
\hline
\end{tabular}

Volume 5 Issue 6, June 2016 www.jijsr.net 